\title{
Should Gonyaulax hyalina and Gonyaulax fragilis (Dinophyceae) remain two different taxa?
}

\author{
Carbonell-Moore M. Consuelo ${ }^{1,{ }^{*}}$, Mertens Kenneth ${ }^{2}$
}

\begin{abstract}
${ }^{1}$ Department of Botany and Plant Pathology, College of Agricultural Sciences, Oregon State University, Corvallis, Oregon 97331-2902, USA

2 Ifremer, LER BO, Station de Biologie Marine, Place de la Croix, BP 40537, Concarneau Cedex F29185, France
\end{abstract}

* Corresponding author : Consuelo M. Carbonell-Moore, email address : carbonem@oregonstate.edu

\begin{abstract}
:
Escalera et al. (2018. Phycologia 57: 453-464) concluded that Gonyaulax hyalina and G. fragilis were the same species. Here, the morphologies of $G$. hyalina and $G$. fragilis were restudied in field samples from different parts of the World Ocean. Results showed that Escalera et al. did not observe G. fragilis, as all strains used in their study belong to one species, G. hyalina. In consequence, it is hereby proposed that the two taxa remain as separate species until further genetic studies are carried out. Additionally, the interpretation of the anterior sulcal plate as unique within gonyaulacoids is considered here inaccurate, as the plate pattern of both species is similar to other species of Gonyaulax, e.g. G. polygramma. We also show that both species may co-occur in the same sample. Their observation of an anterior intercalary plate in cultures of $G$. hyalina was confirmed in field samples.
\end{abstract}

Keywords : Anterior sulcal plate, Gonyaulax polygramma, Misidentification 
Gonyaulax Diesing (Dinophyceae) is a cosmopolitan thecate dinoflagellate genus found in a variety of marine, freshwater and brackish environments (Kofoid 1911, p. 188). It has been extensively studied by both paleontologists and neontologists as some of the extant Gonyaulax are related to the cyst-based genera Spiniferites Mantell and Bitectatodinium Wilson (Fensome et al. 1993, p. 93). Mertens \& Carbonell-Moore (2018) reviewed the historical study of Gonyaulax of which Kofoid (1911) provides an excellent compilation of common species of Gonyaulax. Gonyaulax fragilis (Schütt) Kofoid was first described by Schütt (1895, as Steiniella fragilis) from an unspecified location in the Atlantic Ocean. Gonyaulax hyalina Ostenfeld \& J.Schmidt 1901 was first described by Ostenfeld \& Schmidt (1901) from the Red Sea and the Gulf of Aden. Recently, Escalera et al. (2018) studied three strains which they considered as two Gonyaulax species, namely two strains of G. hyalina, one collected from the Tyrrhenian Sea (Mediterranean Sea) and the other from Tasman Bay (New Zealand), and one strain of purportedly G. fragilis from the Adriatic Sea (Mediterranean Sea). The isolates of the three strains were not identified initially by Escalera et al. (2018). Therefore, there was a possibility that the identifications had not been accurate. Escalera et al. (2018) concluded there were no significant morphological differences between the three studied strains. They also found these strains all clustered in the LSU-rDNA-based-phylogeny, and concluded that the two taxa were the same, adopting the name G. fragilis following the priority rule of the ICN (Escalera et al. used McNeill et al. 2012). Because their investigation was limited to only three strains and no field samples were included, we considered it important to investigate field samples. Through the examination of phytoplankton from different parts of the world (Table S1) using scanning electron microscopy (SEM), this note demonstrates that the external morphology of G. fragilis and G. hyalina is different enough to keep them as separate taxa. All three strains in Escalera $e t$ al. (2018) corresponded to only one species, G. hyalina, as these authors never worked with cells 
of G. fragilis. Phytoplankton samples were prepared for SEM following Carbonell-Moore (2017). In addition, cells were treated with hexamethyldisilazane (HMDS) for one minute after dehydration with 5\%, 20\% 35\% 60\%, $80 \%$ and $100 \%$ ethanol to maintain thecal integrity. The plate nomenclature used here is an adaption of the nomenclature for Gonyaulacales suggested by Alvarez et al. (2016) and used by Mertens et al. (2018).

Figs 1 and 2 show scanning electron micrographs of G. fragilis and G. hyalina respectively. The agreement of external morphology with those of the original description and illustrations (or protologues) by Schütt and Ostenfeld \& Schmidt, respectively, is remarkable (Figs 3 and 5). Although their plate pattern is the same (see Figs 9-12), the cell shape, plate ornamentation and size are not the same. Gonyaulax fragilis (Fig. 1) has a more tapered epitheca than G. hyalina (Fig. 2). In the case of Figs 1 and 2, G. fragilis is much longer $(83 \mu \mathrm{m})$ than $G$. hyalina $(53 \mu \mathrm{m})$, and relatively narrower (65 $\mu \mathrm{m}$ versus $51 \mu \mathrm{m}$, respectively). As only seven cells of G. fragilis versus 14 of G. hyalina were studied, a range of dimensions for G. fragilis cannot be established with certainty. However, G. hyalina presented much smaller sizes (24-53 $\mu \mathrm{m}$ long, $\mathrm{n}=14)$ than $G$. fragilis (41-83 $\mu \mathrm{m}$ long, $\mathrm{n}=7$ ), which does not agree with Ostenfeld \& J. Schmidt's length of $92 \mu \mathrm{m}$ for the holotype. On the other hand, literature accounts have reported G. hyalina with a shorter cell than G. fragilis (see Escalera et al. 2018, their Table 1). However, given the difficulty identifying these taxa, the information in the literature should be treated with caution. For most authors, though, e.g. Kofoid (1911), Lebour (1925) or Balech (1962), G. fragilis is much longer than G. hyalina.

The plate pattern ornamentation is in all likelihood, the most striking difference. Though both species have long parallel ridges running antero-posteriorly, as well as short transversal ridges, it is the number and disposition of the short transversal ridges that makes them quite different. Gonyaulax hyalina shows many more of these short ridges, to the extent that 
ornamentation appears as a rugged topographic map with many close contour lines (e.g. Figs S2, S3, S6, S9, S18, S20). This is not the case of G. fragilis (e.g. Figs S1, S4, S5, S7, S8, S11). In addition, the width and ornamentation of the growth bands is distinct in G. hyalina (e.g. Figs S2, S3, S9, S20, S22) while in G. fragilis they are simpler (e.g. Figs S7, S19, S23). The overlapping margins along precingular and postcingular plates are also different. For example, in the hypothecae of G. fragilis in Figs S19, S21 and S23, the overlapping margin of plate *2' over 1p is shown as a narrow ridge with mostly transverse lines. Figures S20, S22 and S24 of G. hyalina show this overlapping margin as mostly a series of long parallel lines.

It may be argued that in gonyaulacoids plate ornamentation changes with cell development as shown in G. polygramma (Taylor 1962) and Pyrodinium bahamense (Mertens et al. 2015). While Fig. 1 depicts a less-developed cell of G. fragilis (very similar to Schütt's protologue, Fig. 3 this study), Figs S1 and S5 display a well-developed cell of G. fragilis. The cell shows large flanges along not only the sutures but also on the plate surface, e.g. Fig. S1 on plate *6"'. These flanges were never observed in cells of G. hyalina. Despite of its large development, this cell of $G$. fragilis shows an ornamentation not much different from cells with more fragile thecae of the same species, i.e. less-developed cells (e.g. Figs S4, S7). None of the SEM images shown in Escalera et al. 2018 shows any resemblance to our G. fragilis, neither in shape or plate ornamentation, while all their SEM images agree with our images of G. hyalina. This indicates that the strain of $G$. fragilis they used was misidentified.

While the presence of G. hyalina in the Tasman Sea had been confirmed by MacKenzie et al. (2002), the cells of G. fragilis studied by Honsell et al. (1992) may suggest the presence of both species in the Adriatic Sea. Of note is that G. hyalina's typical ornamentation can be observed in their figs 4-6 at the same time that fig. 2 shows a light microscope image of a cell with the typical shape of G. fragilis. 
The misidentification of the strain of the Adriatic Sea (GFA0203) as G. fragilis lead Escalera et al. to incorrectly conclude that all the strains belonged to a same species, which was confirmed by the sequences. The identifications were solely based upon cell shape (Escalera $e t$ al. 2018, p. 460).

In addition, the interpretation of Escalera et al. (2018) of the anterior sulcal plate (Sa) in G. hyalina is inaccurate. These authors labeled plate $* 4$ 'p as the Sa, failing to see that this is the homologue of plate *4'p found in G. polygramma F. Stein (Figs 6-8). Plate Sa is always the plate that conforms the anterior part of the sulcus and is a conservative plate (Graham 1942, p. 7). It is safe to say that the anterior sulcal plate is never found above the sixth precingular plate because it is a sulcal plate associated with the flagellar pore. Figs $9-13$ show the corrected plate pattern tabulation of both species in ventral and apical views including the sulcal region (Fig. 13). This was based on different images of cells in Figs S1-S18. Only those images identified as $G$. hyalina (e.g. Figs S14, S15, S18) agree with Escalera et al.'s images.

The close relationship of $G$. fragilis observed by Escalera et al. in the phylogenetic tree (their fig. 2) with G. polygramma is reflected in having the similar shape and size of the apical plates, especially plates *4'a and *4'p (Figs 6-8, S27-S30). Many Gonyaulax species follow G. spinifera's pattern, where plates $* 4$ 'a and $* 4$ 'p are narrow (Figs 4, S25-S26).

The identification of G. fragilis and G. hyalina using light microscopy is not easy. Taylor (1976) in his monograph of dinoflagellates of the Indian Ocean, reported G. fragilis from only one station. However, the illustration he gave of this species (Fig. S36) is closer to his illustration of another species of Gonyaulax (Fig. S37) and far from our G. fragilis also from the Indian Ocean (Figs 1, S4, S8). On the other hand, some of his illustrations of G. hyalina may correspond to G. fragilis (Figs S33-S35 here). Balech (1962) illustrated a well-developed G. fragilis (Fig. S31) showing plate $* 4$ 'p in the same position as our observations. With respect to 
the sulcus, Balech just mentioned that it narrowed anteriorly, and widened posteriorly as shown in the present study (Fig. 13). Rampi (1943, his fig. 13) also identified G. fragilis from the Ligurian Sea (Mediterranean Sea), which also agrees with our observations of this species.

To conclude:

1. It is recommended here that Gonyaulax fragilis and G. hyalina should be kept as separate species. Escalera et al. 2018 studied only one of these species, namely $G$. hyalina. Further molecular studies would reconfirm the separation of both species.

2. The thecal plate pattern of G. fragilis and G. hyalina is corrected here (Figs. 9 and 10) reflecting our observations of cells from field material. It includes the accurate position of the anterior sulcal plate and the typical ventral pore (VP) of all Gonyaulax species, which was not observed by Escalera et al. (2018).

3. The SEM images of G. fragilis presented here are the first SEM images of this species in the literature. Those shown by Honsell et al. (1992, their figs 4-6) display the distinct ornamentation of G. hyalina not that of G. fragilis.

4. Escalera et al. (2018, fig. 12) found a small anterior intercalary plate surrounded by plates $2 ', * 3 '$ and $4 "$ which was also observed in our samples of G. hyalina (Fig. S18). At this point, we are unable to confirm its presence or absence in $G$. fragilis. This feature also needs to be investigated in other species similar to $G$. polygramma (Fig. S28), where plate *4'p is wide and short, e.g. G. pacifica Kofoid (Fig. S29), G. aff. alaskensis Kofoid (Fig. S30), or G. turbynei Murray \& Whitting (Fig. S27), among others.

5. This study suggests that the two species can coexist, and can be found not only in the same ocean, but sometimes, in the same sample. For example, cells shown in Fig. 1 of G. fragilis and Fig. S20 of G. hyalina were observed in the same sample; 
likewise, the cell shown in figure S7 of G fragilis, was found in the same sample of cells of G. hyalina (Figs 8, S3, S6) (see Table 1S). Figure 2 in Honsell et al. (1992) might be G. fragilis, while their figs 4-6 display the typical ornamentation of G. hyalina.

6. The identification of an isolated cell of either species for culturing, must be ratified with SEM. A light microscopy (LM) identification during isolation proceedings should not be sufficient unless the dinoflagellate species in question can be unequivocally identified under LM, which is neither the case of G. fragilis nor G. hyalina.

\section{REFERENCES}

Alvarez G., Uribe E., Regueiro J., Blanco J. \& Fraga S. 2016. Gonyaulax taylorii, a new yessotoxins-producer dinoflagellate species from Chilean waters. Harmful Algae 58: 815.

Balech E. 1962. Tintinnoinea y dinoflagellata del Pacífico según material de las expediciones Norpac y Downwind del Instituto Scripps de Oceanografía. Revista del Museo Argentino de Ciencias Naturales 'Bernardino Rivadavia' 7: 1-253.

Carbonell-Moore M.C. 2017. The rediscovery of Archaeosphaerodiniopsis verrucosa Rampi (Dinophyceae). European Journal of Phycology 52: 57-63.

Escalera L., Italiano A., Pistocchi R., Montresor M. \& Zingone A. 2018. Gonyaulax hyalina and Gonyaulax fragilis (Dinoflagellata), two names associated with 'mare sporco', indicate the same species. Phycologia 57: 453-464. 
Fensome R., Taylor F.J.R., Norris G., Sarjeant W., Wharton D. \& Williams G. 1993. A classification of fossil and living dinoflagellates. Micropaleontology Special Publication 7: $1-245$.

Graham H.W. 1942. Studies in the morphology, taxonomy, and ecology of the Peridiniales. In: Scientific Results of Cruise VII of the Carnegie during 19828-1929 under command of Captain J.P. Ault, Washington, D.C.: Carnegie Institution of Washington, Publication 542: v + 120 pp.

Honsell G., Cabrini M. \& Darin M. 1992. Gonyaulax fragilis (Schütt) Kofoid: a dinoflagellate from gelatinous aggregates of the Northern Adriatic Sea. Plant Biosystems 126: 749-751.

Kofoid C.A. 1911. Dinoflagellata of the San Diego region, IV. The genus Gonyaulax, with notes on its skeletal morphology and a discussion of its generic and specific characters. University of California Publications in Zoology 8: 187-286.

Lebour M.V. 1925. The dinoflagellates of northern seas. Marine Biological Association of the United Kingdom, Plymouth, UK, 250 pp.

MacKenzie L., Sims I., Beuzenberg V. \& Gillespie P. 2002. Mass accumulation of mucilage caused by dinoflagellate polysaccharide exudates in Tasman Bay, New Zealand. Harmful Algae 1: 69-83.

McNeill J., Barrie F.R., Buck W.R., Demoulin V., Greuter W., Hawksworth D.L., Herendeen P.S., Knapp S., Marhold K., Prado J. et al. 2012. International Code of Nomenclature for algae, fungi, and plants (Melbourne Code). Regnum Vegetabile. Koeltz Scientific, Melbourne, Australia. 240 pp.

Mertens K.N. \& Carbonell-Moore M.C. 2018. Introduction to Spiniferites Mantell 1850 special issue. Palynology 42: 1-9. 
Mertens K.N., Carbonell-Moore M.C., Pospelova V., Head M.J., Highfield A., Schroeder D., Gu H., Andre K.B., Fernandez M., Yamaguchi A. et al. 2018. Pentaplacodinium saltonense gen. et sp. nov. (Dinophyceae) and its relationship to the cyst-defined genus Operculodinium and yessotoxin-producing Protoceratium reticulatum. Harmful Algae 77: 57-77.

Mertens K.N., Wolny J., Carbonell-Moore C., Bogus K., Ellegaard M., Limoges A., de Vernal A., Gurdebeke P., Omura T., Al-Muftah A. \& Matsuoka K. 2015. Taxonomic reexamination of the toxic armoured dinoflagellate Pyrodinium bahamense Plate 1906: can morphology or LSU sequencing separate P. bahamense var. compressum from var. bahamense? Harmful Algae 41: 1-24.

Ostenfeld C.H. \& Schmidt J. 1901. Plankton fra det Röde Hav og Adenbugten. Videnskabelige Meddelelser fra den naturhistoriske Forening i Kjøbenhavn 3: 141-182.

Rampi L. 1943. Su qualche Peridinea nuova o rara delle acque di Sanremo. Atti della Società Italiana di Scienze Naturali e del Museo Civico di Storia Naturale di Milano 82: 151157.

Schütt F. 1895. Die Peridineen der Plankton-Expedition. In: Ergebnisse der Plankton-Expedition der Humboldt-Stiftung (Ed. by V. Hensen), pp. 170. Lipsius \& Tischer, Kiel; Leipzig.

Schütt F. 1896. Peridinaceae. In: Die Natürlichen Pflanzenfamilien nebst ihren Gattungen und wichtigeren Arten, insbesondere den Nutzpflanzen, unter Mitwirkung zahlreicher hervorragender Fachgelehrten (Ed. by A. Engler \& K. Prantl), pp. 91. Verlag von Wilhelm Engelmann, Leipzig.

Taylor F.J.R. 1962. Gonyaulax polygramma Stein in Cape waters: a taxonomic problem related to developmental morphology. The Journal of South African Botany 28: 237-242. 
Taylor F.J.R. 1976. Dinoflagellates from the International Indian Ocean Expedition. A report on material collected by the R.V. “Anton Bruun” 1963, 1964. Bibliotheca Botanica 132: 1234.

\section{FIGURE CAPTIONS}

Figs. 1-8. Comparison of Gonyaulax fragilis and G. hyalina with other Gonyaulax species.

Fig. 1. Scanning electron photomicrograph (SEM) of G. fragilis. Ventral view. Cell from the Indian Ocean. Compare cell outline similarity with Schütt's drawing from 1896 (Fig. 3). White arrowhead points to plate *4' p, which was interpreted by Escalera et al. (2018) as the anterior sulcal (Sa).

Fig. 2. SEM of G. hyalina. Ventral view. Cell from the central equatorial Pacific Ocean. Compare similarity of cell outline with original illustration by Ostenfeld \& J. Schmidt (1901) (Fig. 5). Black arrowhead points to plate *4' p, which was interpreted by Escalera et al. (2018) as the anterior sulcal $(\mathrm{Sa})$.

Fig. 3. Schütt's drawing of Steniella fragilis [= G. fragilis (Schütt) Kofoid] from 1896, ventral view.

Fig. 4. Close-up of ventral area of a cell of G. spinifera (SEM), Mediterranean Sea; same cell as Fig. S26. Notice narrowness of plates *4' a, p and 6" compared to homologues in $G$. polygramma (Fig. 7).

Fig. 5. Original drawing of ventral view of G. hyalina by Ostenfeld \& J. Schmidt (1902).

Fig. 6. Close-up of ventral area of same cell of G. fragilis in Fig. 1. Note similarity of plates *4' a, p and 6" to those in G. polygramma (Fig. 7), and much wider than in G. spinifera (Fig. 4). Fig. 7. Close-up of ventral area of G. polygramma (SEM). Note wider plates *4' a, p and 6" compared to homologues in G. spinifera (Fig. 4). Cell from the central equatorial Pacific Ocean. 
Fig. 8. Close-up of ventral area of G. hyalina from Indian Ocean (SEM), same cell as Fig. S18. Note similarity of plates *4' a, p and 6" to homologues in G. polygramma (Fig. 7), and much wider than in G. spinifera (Fig. 4).

Scale bars: Figs 1, 2: $20 \mu \mathrm{m}$; Figs 6, 7: $10 \mu \mathrm{m}$; Figs 4, 8: $5 \mu \mathrm{m}$.

Figs 9-12. Line drawings of plate pattern tabulation of Gonyaulax fragilis and G. hyalina. Cingular plates not included. For sulcal area, refer to Fig. 13. A combination of Kofoidean and plate homology nomenclature is used (see text for details). 1': first apical plate. * 3 ': homologue of the third apical plate; $* 4$ 'a: homologue of the anterior fourth apical plate. $* 4$ 'p: homologue of the posterior fourth apical plate; Sa: anterior sulcal plate; Ssa: left anterior sulcal plate; 1p: first posterior intercalary plate; *2"', *5"', *6"': homologues of the second, fifth and sixth postcingular plates, respectively.

Fig. 9. Ventral view of G. fragilis. Dash lines indicate sulcal plates which are usually hidden.

Fig. 10. Ventral view of G. hyalina. Dash lines indicate sulcal plates which are usually hidden.

Fig. 11. Apical view of G. fragilis. Dash lines indicate where plate 1a should be, whose presence was not confirmed.

Fig. 12. Apical view of $G$. hyalina with conspicuous plate 1a. Epithecal plate nomenclature is the same used by Escalera et al. (2018). Hypothecal plate nomenclature follows that used by Mertens et al. (2018).

Fig. 13. Line drawings of the sulcal area of a typical gonyaulacoid as represented by the sulcus of Gonyaulax fragilis (similar in G. hyalina) with flagella pore area shown in grey. Dash lines indicate sutures not visible generally as they lay under sulcal list of plate 1p. Sa: anterior sulcal plate; Sda: right anterior sulcal plate; Sdp: right posterior sulcal plate; Sp: posterior sulcal plate; Ssa: left anterior sulcal plate; Ssp: left posterior sulcal plate; 1p: first 
posterior intercalary plate; $\mathrm{C}_{\mathrm{n}}: \mathrm{n}$ cingular plate; $* 4$ p: homologue of the posterior fourth apical plate. 


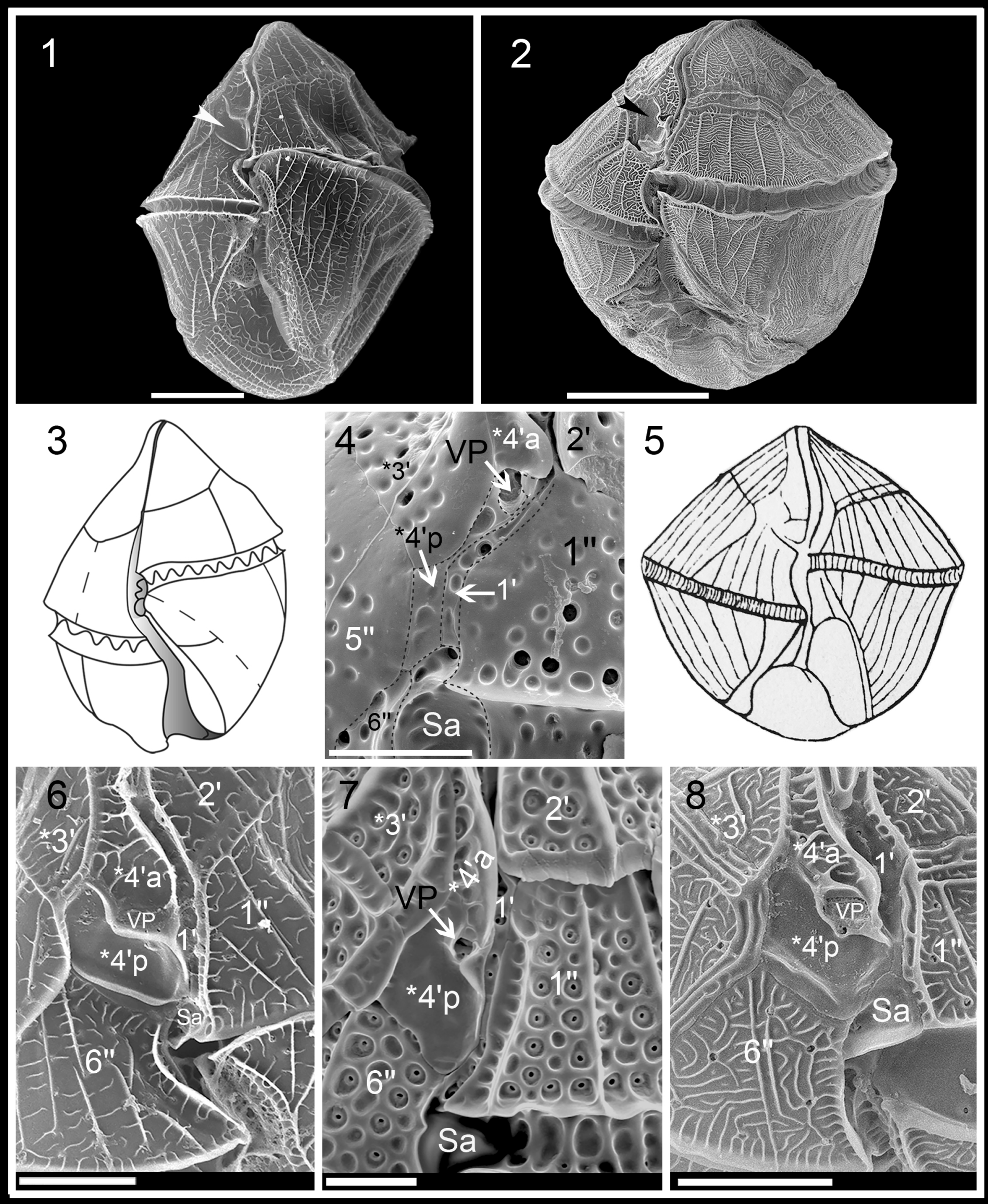



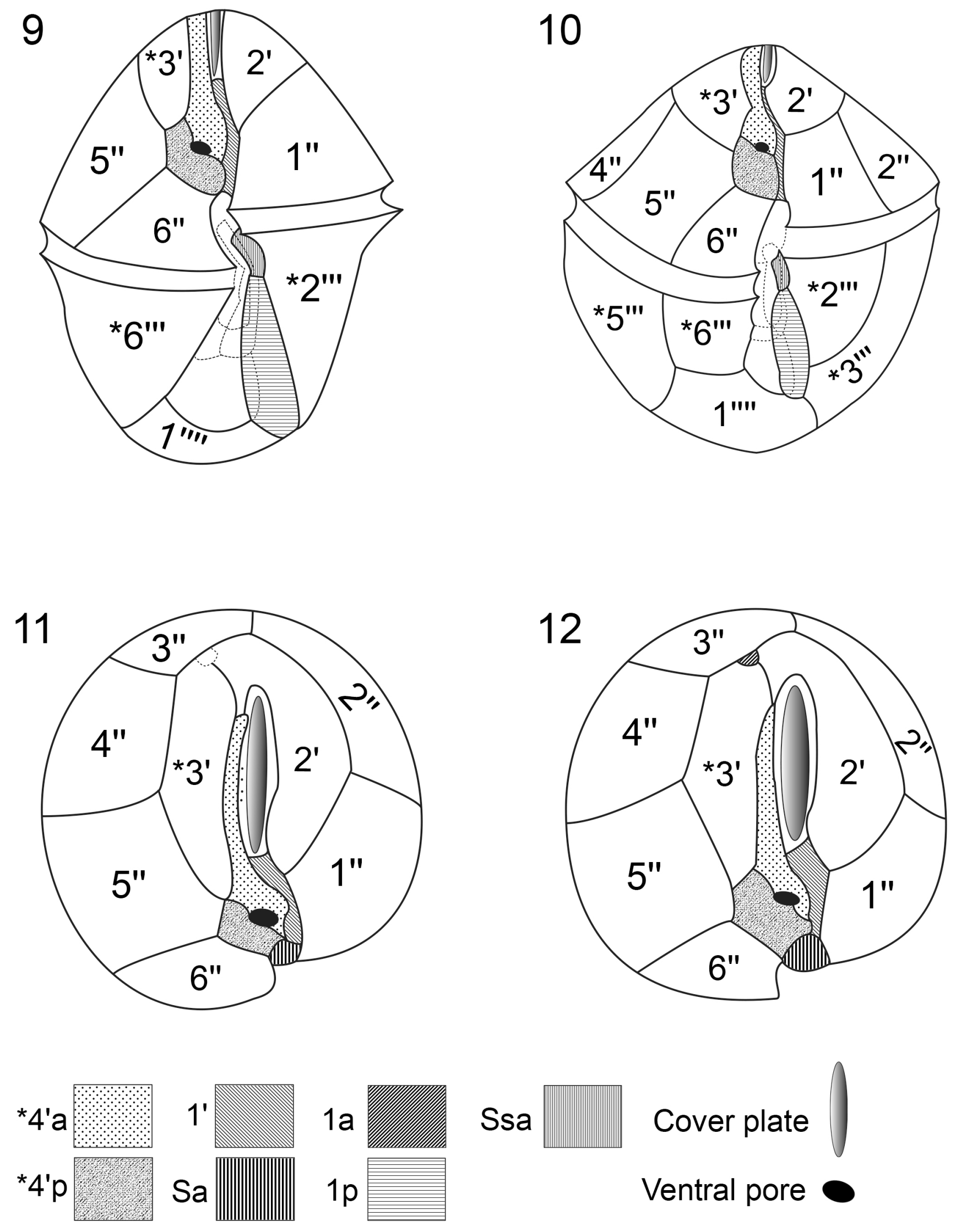